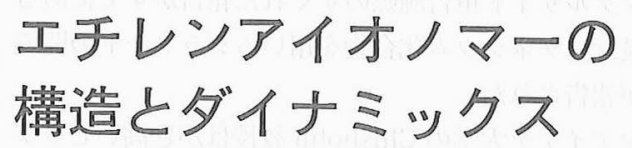

吉水 広明 名古屋工業大学工学部材料工学科・助手

1991 年 4 月, 博士課程を終了したばかりの私は名工 大の辻田教授の研究グループに加えさせていただいた. 教官スタッフは教授, 助教授之私の 3 名で学生は約 20 人. 学生時代に所属していた研究室と比べると大きく, 研究テーマもかなり広範囲に渡っていた，実際，環境に 慣れるのにちょっとした時間がかかった。 そんな折り， 嬉しいことに名工大に $400 \mathrm{MHz}$ の NMR 装置が導入さ れることになったささっそくエチレンーメタクリル酸共 重合体执よびその金属塩（エチレンアイオノマー）の構 造解析をすることにした。一般にアイオノマーとは少量 （通常 $10 \%$ 以下）の酸基を有する比較的低誘電率のホス トポリマー（ポリエチレン，ポリスチレン等）を金属イ オン等で中和したものである. アイオノマー中のイオン 基は，お互いの静電的相互作用により会合し，イオン会 合体を形成するのでホストポリマーには見られない物性 が発現する.とりわけエチレンアイオノマーは, 1964 年にデュポン社が “Surlyn” の商品名で市販して以来, 包装材, 成型品, エラストマー，接着フィルム等工業的 に広く利用されている. したがって, その物性や構造に ついては小角 X 線散乱, 力学㧍よび誘電分散, 熱分析, IR 等で広く研究されている。にあかかわらず会合体の 構造や機能, ホストポリマーの動・静的構造の詳細につ いてはいまだ完全に解明されたとは言い難い、また, NMR 法を用いた研究例は意外にほとんどない。 アイオ ノマーについて調べるほど固体 NMR 法を用いる意義を ひしひしと感じた.

実際に装置が設置され稼動するまでには予想以上に時 間がかかり，いらいらする時期ああったが，その間に， スピンプローブ ESR 法や DSC による検討を行った．工 チレンアイオ/マーはホストポリマーであるポリエチレ ンが結晶性ポリマーであるので，イオン会合体の形成に 伴うエチレン鎖の構造や分子運動性がどのように変化す るのかを検討することは重要である，スピンプローブ含 有試料の ESR スペクトルを観測し，その最大分離幅か ら分子運動性を検討した結果，エチレンアイオノマーの マトリックス相は動的に不均一な構造であること，イオ ン会合体の増加に伴いその分布が変化することが碓認さ

\section{Structure and Dynamics of Ethyleneionomer}

(1)生年 (2)大学 (院) の研究室名 と研究テーマ (3)現在の専門分野 (1)1963 年 (2)東京工業大学大学院 理工学研究科/安藤盡研究室/固体 高分解能 ${ }^{13} \mathrm{C}$ NMR による羊毛ケラ チンおよびSーカルボキシメチル化 ケラチンの構造研究 (3)高分子物理 化学・磁気共鳴分光学

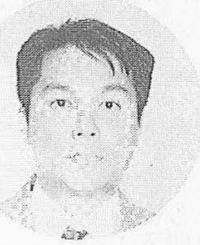

れた. また，DSC による検討の結果，エチレンアイオノ マーには, 溶融状態からの冷却過程で生成する結晶之冷 却後室温で生成する結晶という生成過程の異なる 2 種 類の結晶が存在すること, 二つの結晶はイオン会合体の 存在と相関があることが明らかとなった．また，エチレ ンーアイオ/マーの物性に熱履歴が観察されるのはこの 結晶構造に一因があると結論できた。

果たして固体 NMR による検討はこれらの結論に対し てどのような補足・発展が得られるのであろうか. いよ いよ装置が稼働し, 試料をセット, 測定が始まる、最む 楽しみな時間の一つである. エチレンアイオノマーの ${ }^{13} \mathrm{C}$ CP/MAS NMR スペクトルには, メチレン炭素由来 の大きなピークと, メチル炭素および四級炭素, カルボ 一ル炭素由来の小さなピークがそれぞれ観測された， 2 本のエチレン炭素ピークは, ポリエチレンのデータを参 考にして, 低磁場側を結晶部に高磁場側を非晶部にそれ ぞれ帰属した．ピーク強度はイオン会合体の存在により 結晶化度が異なることと対応していた。それぞれのスピ ン一格子緩和時間を見積ると, 結晶部のそれは高密度ポ リエチレンで報告されている值よりあ非常に短かった。 今のところ,これは間接的には結晶の大きさが高密度ポ リエチレンに比べ小さいことを反映した現象之考察して いる．DSCで確認された熱処理により結晶が成長する ことはプロトンのスピン拡散現象からあ再確認できた。 さらに,イオン会合体に関与しているメタクリル酸は, 関与していないそれよりあ運動性がより束縛される傾向 にあることが明らかになった。

現在は, イオン会合体そのあのの観察にチャレンジし ている. 今後も生体系を含め, 高分子の構造の詳細を比 較的新しい方法である固体 NMR を用いて積極的に解析 していきたいと考えている. 